\title{
Malaria prophylaxis with atovaquone-proguanil caused fewer gastrointestinal adverse events than chloroquine-proguanil
}

Høgh B, Clarke PD, Camus D, et al, and the Malarone International Study Team. Atovaquone-proguanil versus

chloroquine-proguanil for malaria prophylaxis in non-immune travellers: a randomised, double-blind study. Lancet 2000 Dec 2;356:1888-94.

QUESTION: In travellers who are not immune to malaria, is malaria prophylaxis with atovaquone proguanil equivalent to that with chloroquine proguanil for adverse events (AEs)?

\section{Design}

Randomised (allocation concealed*), blinded (clinicians and patients),* placebo controlled trial with follow up at 7,28 , and 60 days after leaving a malaria endemic area.

\section{Setting}

21 travel clinics in Denmark, the UK, France, Germany, the Netherlands, South Africa, and Canada.

\section{Participants}

1083 participants (mean age 36 y, $52 \%$ men, $96 \%$ white) who weighed $>50 \mathrm{~kg}$, were age $\geqslant 14$ years, were in good health, and planned to travel $\leqslant 28$ days in Africa (63\%) or other Plasmodium falciparum endemic areas. Exclusion criteria included a history of seizures; psychiatric or neurological disorders; cardiac, hepatic, or renal dysfunction; pregnancy; alcoholism; malaria within the previous 12 months; or travel to a malaria endemic area within the previous 60 days. Follow up was $94 \%$ at 7 days and $93 \%$ at 60 days.

\section{Intervention}

540 participants were allocated to atovaquone, 250 $\mathrm{mg} /$ day, and proguanil hydrochloride, $100 \mathrm{mg} /$ day, from 1 to 2 days before to 7 days after travel (and placebos for chloroquine proguanil). 543 participants were allocated to chloroquine, $310 \mathrm{mg}$ /week, from 7 days before to 28 days after travel, and proguanil, 200 $\mathrm{mg}$ /day, from 1 to 2 days before to 28 days after travel (and placebos for atovaquone proguanil).

Ontario Ministry of Health; PSI; Glaxo Wellcome.

For correspondence: Malarone Publication Coordinator, Room 50-3505B, Glaxo Wellcome Inc, 5 Moore Drive, Research Triangle Park, $N C$ 27709, USA. Fax +1 9193150377.

\section{Main outcome measure}

Number of AEs 7 days after return from a malaria endemic area.

\section{Main results}

Analysis was by intention to treat. Fewer drug attributed AEs (nausea, abdominal pain, and vomiting) and treatment limiting events occurred in the group

Atovaquone-proguanil v chloroquine-proguanil for drug attributed gastrointestinal (GI) adverse events and treatment limiting events in participants not immune to malariat

\begin{tabular}{|c|c|c|c|c|}
\hline Events at 7 days & $\begin{array}{l}\text { Atovaquone- } \\
\text { proguanil }\end{array}$ & $\begin{array}{l}\text { Chloroquine- } \\
\text { proguanil }\end{array}$ & $\operatorname{RRR}(95 \% \mathrm{Cl})$ & NNT (Cl) \\
\hline All adverse events & $22 \%$ & $28 \%$ & $23 \%$ (4 to 38$)$ & 16 (9 to 102$)$ \\
\hline Any Gl event & $12 \%$ & $20 \%$ & $41 \%(21$ to 56$)$ & 12 (8 to 28$)$ \\
\hline Nausea & $2 \%$ & $7 \%$ & $74 \%$ (46 to 87$)$ & 20 (13 to 39$)$ \\
\hline Abdominal pain & $3 \%$ & $6 \%$ & $50 \%(9$ to 73$)$ & 34 (18 to 230$)$ \\
\hline Vomiting & 0 & $2 \%$ & $100 \%(65$ to 100$)$ & 46 (26 to 83$)$ \\
\hline Any treatment limiting event & $0.2 \%$ & $2 \%$ & $90 \%$ (40 to 98$)$ & 57 (29 to 162$)$ \\
\hline
\end{tabular}

†Abbreviations defined in glossary; RRR, NNT, and $\mathrm{Cl}$ calculated from data in article.

receiving atovaquone-proguanil than in the group receiving chloroquine-proguanil (table). At 60 days, no participants in the atovaquone-proguanil group and 3 in the chloroquine-proguanil group had confirmed $P$ falciparum malaria $(\mathrm{p}=0.08)$.

\section{Conclusion}

Atovaquone-proguanil caused fewer gastrointestinal adverse events than chloroquine-proguanil in travellers who were not immune to malaria.

*See glossary.

\section{COMMENTARY}

The study by Høgh et al addresses the tolerability of 2 malaria drug prophylaxis regimens. Balancing the risks for developing malaria against the AEs of the drug prophylaxis makes the choice of drug difficult for many travellers to malaria endemic areas. The underlying problem in malaria drug prophylaxis is in the public perception of risk. ${ }^{1-3}$ Because travellers want to avoid AEs, the antimalarial drugs that cause fewer AEs will be used more frequently. The atovaquone-proguanil combination is effective in treating drug resistant malaria; however, it is too expensive to be used by many people in the developing countries in which it was tested. ${ }^{4}$ Nevertheless, it can still be useful to travellers, which is what the trial by Høgh $e t$ al evaluates.

It is not easy to show comparative benefits of 1 prophylactic regimen over another when AEs are few, but it seems unlikely that people will benefit from a regimen if they discontinue the drug while still exposed to the risk for infection. The trial by Høgh et al is instructive because it shows that the drug recommended for many years, chloroquine, can cause prophylaxis limiting events. The results are important for travellers because they show higher adherence with proguanil and atovaquone, a regimen effective against drug resistant malaria. The findings provide evidence to support a new drug option for preventing malarial infection in travellers.

Paul Garner, MBBS, MD Liverpool School of Tropical Medicine Liverpool, $U K$

1 Reid AJ, Whitty CJ, Ayles HM, et al. Malaria at Christmas: risks of prophylaxis versus risks of malaria. BMJ 1998;317:1506-8.

2 Croft AM, Garner P. Mefloquine for preventing malaria in non-immune adult travellers. Cochrane Database Syst Rev 2001;(1):CD000138.

3 Beck University. Risk society:towards a new modernity. London: Sage Publications, 1992.

4 Nosten F. Prophylactic effect of Malarone against malaria: all good news? Lancet 2000;356:1864-5. 